\title{
Protowenella (Mollusca) from the Cambrian of Peary Land, eastern North Greenland
}

\author{
John S. Peel
}

Grønlands Geologiske Undersøgelse, Øster Voldgade 10, DK-1350 København K, Danmark

Protowenella is a minute planispiral mollusc with characteristic circumbilical channels on the internal mould, first described from two Middle Cambrian localities in Australia by Runnegar \& Jell (1976). BergMadsen \& Peel (1978) subsequently described Protowenella from the Middle Cambrian of Denmark and, on the basis of a functional morphological interpretation, supported the suggestion of Runnegar \& Jell that the genus was a member of the class Monoplacophora.

Protowenella has now been recovered from thin bedded, dark dolomites outcropping on the eastern side of Hans Tavsens Iskappe, south-west Peary Land, eastern North Greenland. The samples (GGU collection 271718) were collected near the top of the as yet un-named formation 2 of the Brønlund Fjord Group (Peel, 1979). Treatment with acetic acid yielded a rich fauna including inarticulate brachiopods, eocrinoids, conodonts and phosphatic internal moulds of helcionellaceans, pelagiellaceans, stenothecoidids, chancelloriids, and Protowenella. Associated trilobites are indicative of a late Middle Cambrian age (see Palmer \& Peel, this report).

The two specimens of Protowenella so far located in the sample are less than $1 \mathrm{~mm}$ in length. Both are internal moulds which appear open coiled on account of the loss of shell material. Each specimen is a little more than a half of a whorl, although the aperture is not preserved. The characteristic circumbilical channels are visible in both specimens. The apical termination in each of the internal moulds is smoothly convex, suggesting the presence of an imperforate septum of the type known to occur in many gastropods and some monoplacophorans. There are no preserved indications of shell ornamentation.

The distribution of Protowenella, from Australia to Denmark and North Greenland, is remarkable, and all occurrences are of Middle Cambrian age. While data are clearly still too scarce for satisfactory evaluation, the records are of interest in indicating a potential for correlation using this and other molluscs to supplement the dominantly trilobite based biostratigraphy employed in the Cambrian.

\section{References}

Berg-Madsen, V. \& Peel, J.S. 1978: Middle Cambrian monoplacophorans from Bornholm and Australia, and the systematic position of the bellerophontiform molluses. Lethaia 11, 113-125.

Peel, J.S. 1979: Cambrian - Middle Ordovician stratigraphy of the Adams Gletscher region, south-west Peary Land, eastern North Greenland. Rapp. Grønlands geol. Unders. 88, 29-39.

Runnegar, B. \& Jell, P.A. 1976: Australian Middle Cambrian molluscs and their bearing on early molluscan evolution. Alcheringa 1, 109-138. 